\title{
Improving Students' Motivation to Learn in the Classroom
}

\author{
Naeli Nurlaeli \\ Indonesia University of Education \\ Nonformal Education (PLS-FIP) \\ Bandung, Indonesia \\ E-mail address: nellyhasanudin@gmail.com
}

\begin{abstract}
Motivation to learn is connected with the desire or willingness of students to participate in learning so that students' motivation to have a role in the achievement of student learning and performance. Facts found in the field show that in general students need to bring learning motivation stimulus. Developing students' motivation should be one of the targets of teachers in teaching. This paper will examine how the efforts that teachers can do to improve students' motivation in the learning process in the classroom. Based on the results of the study can be understood that the learning process of the teachers have a direct impact on students' motivation. Almost every activity that teachers do in the classroom provide positive or negative influence on the students' motivation. How teachers create learning environments that support the learning needs and foster an interest of students to learn a positive effect on student motivation. Every teacher should realize the importance of students 'motivation in learning achievement and understand their role in cultivating students' motivation so that learning can take place effectively with optimal results.
\end{abstract}

\section{Keywords; motivation, learning, the role of teachers}

\section{INTRODUCTION}

Each individual undergoing a process of learning throughout life, either intentionally or unintentionally, are consciously or unconsciously. The learning process is deliberate and conscious by studying subjects of which took place in the educational process in an educational institution that involves the presence of teachers and there was an interaction between the subjects of learning and teaching that we are familiar with the term learning process (PBM). To obtain the optimum learning, the learning process should be done consciously and deliberately and well organized [1].

In the process of learning to be aware of what can encourage the student to learn properly or her to have a motive to think and concentrate, plan and carry out activities related or supporting learning. From the description it is clear that a strong motive is necessary for the study [2]

It has been reported that student motivation is connected with the desire of students to participate in the learning process and concerning the underlying reason for student involvement, or lack thereof, in the academic activities [3].

The study was conducted at a tutoring agency where students as learners follow the learning process in the place after hours of study at the school is over. So, we need a high learning motivation for students to attend, follow and participate actively in the learning process in the learning guidance.

\section{GROWING ROLE IN TEACHER STUDENT LEARNING MOTIVATION MOTIVATION TO LEARN}

Each individual undergoing a process of learning throughout life, either intentionally or unintentionally, are consciously or unconsciously. Learning can be regarded as a change in behavior based on the experience gained. Learning is a process attempts person to obtain a new change in behavior as a whole, as a result of his own experience in interaction with the environment [2].

The learning process is deliberate and conscious by studying subjects of which took place in the educational process in an educational institution that involves the presence of teachers and there was an interaction between the subjects of learning and teaching that we are familiar with the term learning process (PBM). To obtain the optimum learning, the learning process should be done consciously and deliberately and well organized.

Many factors affect the learning process and results. Broadly speaking, the factors that influence learning can be classified into internal factors (from within) themselves the subject of study and external factors (external) person of the subjects studied. Internal factors concerning physical factors, psychological factors, and the fatigue factor.

Motivation is one of the psychological factors that play a role in the learning process. Desire or urge to learn is called motivation. Motivation is an essential condition of learning. The learning process will be successful if the subjects studied had the desire to learn, learning outcomes are optimal when there is motivation. The issue of motivation depends on the element of experience and interest. Frandsen stated there are some things that encourage someone to learn, namely: (1) the nature curious and want to investigate the wider world; (2) the nature of creative people who learn and the desire to always go forward; (3) the desire to gain sympathy from parents, teachers and friends; (4) the desire to correct past failures with new business, either by cooperation and competition; (5) the desire to get a sense of security when it learned the lesson; (6) their reward or punishment as the end of the study ${ }^{[1]}$. 
Motivation plays an important role in student achievement and school performance. It has been reported that student motivation is connected with the desire of students to participate in the learning process and concerning the underlying reason for student involvement, or lack thereof, in the academic activities ${ }^{[3]}$.

Based on some of these studies we can see that: (1) Motivation to learn is one of the factors that affect learning outcomes. Students 'motivation is influenced by several factors such as: parents and teachers, peers, creative content, the learning environment, the students themselves, the student's interest in creative content, students' perceptions regarding the usefulness of the material, the difficulty level of the assignment of teachers; (2) Teachers have a direct influence on students' motivation. Almost every activity that teachers do in the classroom provide positive or negative influence on the students motivation. How teachers create learning environments that support the learning needs and foster an interest of students to learn a positive effect on student motivation.

Teaching and learning interactions is the interaction activities of the faculty carry out the task of teaching the learners (students, pupils / subject of study) who are conducting learning activities. Interaction between teachers with learners, expected to be the motivation process. That is how the process of the interaction of the teacher is able to provide and develop motivation and reinforcement to the learners / students / learners subjects, in order to perform learning activities optimally.

In the management of teaching and learning interactions, tutor at least two basic capital, namely the ability to design programs and the skills to communicate the program to the participants. Both capital is formulated into ten competencies tutor as follows: (1) control of learning materials (content material), (2) is able to manage the program of teaching and learning, (3) be able to manage classes, namely to provide conditions conducive to the process of teaching and learning , (4) use of media and learning resources, (5) to master the foundations of education, (6) manage the interaction of teaching and learning, (7) assess student achievement for the sake of teaching, (8) to know the functions and programs, guidance and counseling in schools, (9) identify and administer the schools, (10) to understand the principles and interpret the results of educational research for the purpose of teaching ${ }^{[1]}$.

\section{METHOD}

\section{RESULT \& DISCUSSION}

Teaching and learning interactions is the interaction between the activities of faculty who carry out the task of teaching the learners (students, pupils / subject of study) who are conducting learning activities. Teachers should be able to provide and develop the motivation to the participants so that the learning process can take place optimally.

Decreased motivation in learning that found by previous researchers may be caused by the lack of integration between the lives of students in a school environment. Thoonen explained that the school environment is not tuned to the interests, needs and values of students will affect their identification to the school and as a result, will cause a decrease in their motivation in the long term. (Thoonen et al., N.d.).

Based on some of the explanation we can understand how important the role of teachers in raising and developing the students' motivation. Teachers who have the ability to design exciting learning program to accommodate the needs and interests of students and able to manage and organize learning well be able to attract students 'attention and arouse students' motivation.

To raise students' motivation required of teachers who have the competence, passion and high motivation to provide the best instruction given motivation is a complex concept and is associated with other concepts such as interest, self-concept, attitude and so on. Students who seemed unmotivated may in fact be motivated but not the things that are expected of teachers. Or maybe the students sufficiently motivated to do well in school, but at the same time there are other forces, such as friends, who encouraged her to not do well in school.

Some of the ways teachers can do to improve student motivation without having to reorganize massive class including through:

- Awaken the curiosity of students and the desire to conduct exploration

- Use materials that have been known as an example to make students more easily understand the teaching materials

- Occasional teachers can do things that are incredible

- Use simulations and games

- Giving verbal praise when the student reaches a student's success slightest.

- Stimulate desire to reward students

- Use the test in grades wisely

- Ask students to use the things they have learned previously

- Teachers need to understand and oversee the social atmosphere of the school, because it is a big influence on the student

- Teachers need to understand the power relationship between teachers and students; someone will be able to influence other people's motives when he had a form of social power (French \& raven 1959)

Based on several studies of the discussion can be concluded that:

- Motivation to learn is one of the factors that affect learning outcomes. The learning result is optimal if there is motivation. Motivation will always determine the intensity of the effort of learning for students. Motivation serve as a spur efforts and achievements. 
- Students' motivation is influenced by several factors such as:
a. Parents \& Teachers
b. Friends of the same age
c. Content material
d. Learning environment
e. Students itself
f. Interest from students on creative content
g. Students' perceptions about the usefulness of the material
h. The level of difficulty assignment of teachers

- Teachers have a direct impact on students' motivation. Almost every activity that teachers do in the classroom provide positive or negative influence on the students motivation. How teachers create learning environments that support the learning needs and foster an interest of students to learn a positive effect on student motivation.:

\section{REFERENCES}

[1] Sardiman. (2010). Interaksi dan Motivasi Belajar. Bandung: Rineka Cipta.

[2] Slameto. (2013). Belajar \& Faktor-faktor yang mempengaruhi. Jakarta : Rineka Cipta.

[3] Khamis, V., Dukmak, S., \& Elhoweris, H. (2008). Factors affecting the motivation to learn among United Arab Emirates middle and high school $\begin{array}{lll}\text { students, } & \text { (November } & \text { 2014), }\end{array}$ http://doi.org/10.1080/03055690701811297

[4] Thoonen, E. E. J., Sleegers, P. J. C., Peetsma, T. T. D., \& Oort, F. J. (n.d.). Can teachers motivate students to learn ?, (November 2013), 3741. http://doi.org/10.1080/03055698.2010.507008

[5] Hancock, D. R. (2010). the Classroom Influencing Postsecondary Students 'Motivation to Learn in the Classroom, (October 2014), 37-41. http://doi.org/10.1080/87567550209595877

[6] Thoonen, E. E. J., Sleegers, P. J. C., Peetsma, T. T. D., \& Oort, F. J. (n.d.). Can teachers motivate students to learn ?, (November 2013), 3741. http://doi.org/10.1080/03055698.2010.507008 